\title{
HCD法によるTiNコーティング鋼の耐孔食，耐すきま腐食性
}

\author{
黒河圭子*, 小平隆志*，中山佳則 ${ }^{* *}$, 滝沢貴久男 ${ }^{* *}$, 今井八郎***
}

\section{Pitting and Crevice Corrosion Resistance of TiN-Coating Steels Prepared by HCD}

\author{
Keiko KUROKAWA*, Takashi ODAIRA*, Yoshinori NAKAYAMA*", \\ Kikuo TAKIZAWA** and Hachiro IMAI**
}

\begin{abstract}
TiN films were variously deposited onto SUS 304 stainless steel by an ion plating process using hollow cothode discharge (HCD). The pitting and crevice corrosion resistance of the TiN-coated specimens was estimated in chloride solutions, mainly by the electro-chemical method. The results obtained are as follows ; The effects on corrosion resisitance of a TiC coating under the TiN film and of the temperatuer of deposition were not clear, but the effect of a $\mathrm{Ti}$ undercoating was evident. Corrosion morphology was also affected by $\mathrm{Ti}$ undercoating.

In specimens without $\mathrm{Ti}$ undercoating, the pitting and crevice corrosion resistance was decreased by TiN coating, whereas with $\mathrm{Ti}$ undercoating the pitting potential and starting potential to crevice corrosion became more noble. Accordingly the pitting and crevice corrosion resistance was improved by TiN coating, but the repassivation potential became less nobel and repassivation was restrained as corrosion started.
\end{abstract}

Key Words : Corrosion, Ion Plating, HCD Process, Titanium Nitride, Stainless Steel

\section{1. 緒言}

イオンプレーティングにより得られたTiN皮膜は，美 麗で, 硬度が高く耐摩耗性等に優れていることが知られ

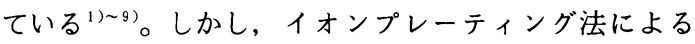

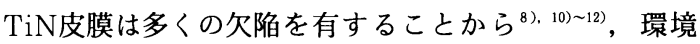
遮断効果が小さく，一般に，湿式環境下に掉いて素地金 属の耐食性を改善させることは容易でないとされている。

本研究では，湿式環境下におけるTiN皮膜の実用性を 検討するため, HCD (Hollow Cathode Discharge) 式の工業炉にて, 種々の条件でステンレス鋼上にTiN皮 膜を形成し, 主に電気化学的方法により塩化物水溶液中 での耐孔食性及び耐すきま腐食性の評価を行った。また, 腐食形態などの面からもその腐食挙動について考察し, 同時に, Tiアンダーコートや積層の効果, 皮膜形成温 度の耐食性に与える影響についても検討した。なお，本 研究におけるTiアンダーコート及びTiC皮膜による積層 化のねらいは, 厚さ数 $\mu \mathrm{m}$ 程度の比較的薄い皮膜によっ て，優れた環境遮断効果を得ることにある。

*三洋電機㑣空調研究センター（テ370-05 群馬県邑楽郡大泉 町坂田180)

Air-Conditioning R \& D Center, Sanyo Electric Co., Ltd. (180, Sakata, Oizumi-machi, Ora-gun, Gunma 370-05)

**三洋電機(㑣)（产369-01 埼玉県北足立郡吹上町前砂160-1） Sanyo Electric Co., Ltd. (160-1, Maesuna, Fukiagemachi, Kitaadachi-gun, Saitama 369-01)

*** 芝浦工業大学（宁108 東京都港区芝浦3-9-14）

Shibaura Inst. of Tech.(9-14, Shibaura 3-chome, Minatoku, Tokyo 108)

\section{2. 実験方法}

\section{1 供試材およひ皮膜形成処理}

基板には, SUS 304 鋼 (C: $0.052, \mathrm{Si}: 0.51, \mathrm{Mn}$ : 1.24, $\mathrm{P}: 0.026, \mathrm{~S}: 0.027, \mathrm{Ni}: 8.62, \mathrm{Cr}: 18.16 \mathrm{wt} \%)$ を用いた。基板形状は，孔食電位測定用を $15 \times 15 \times \mathrm{t} 5$ $\mathrm{mm}$ ，自然浸せきによる耐孔食性評価用を $\phi 35 \times \mathrm{t} 5$ $\mathrm{mm}$ とした。また，すきま腐食再不動態化電位 $\left(E_{\mathrm{R}}\right)$ 測 定あるいは自然浸せきによる耐すきま腐食性評価用の試 験片は， $\phi 18$ 及び $\phi 32 \times \mathrm{t} 5 \mathrm{~mm}$ とし, 中央に $\phi 3 \mathrm{~mm}$ の穴をあけた。これらの試料は，表面を湿式研磨（\# 1000）後ダイヤモンドペースト研磨し，トリクロールエ チレン及びアセトン中で超音波洗浄してからイオンプレー ティング処理を施した。

イオンプレーティング処理にはHCD式の工業炉を用 い，まず槽内を $6.65 \times 10^{-3} \mathrm{~Pa}$ まで真空排気した後 $\mathrm{Ar}$ スを導入し，基板にー-300Vのバイ?ス電圧を印加して スパッタクリーニングを行った。次に, $1.06 \times 10^{-1} \mathrm{~Pa}$ のガス圧， $-70 \mathrm{~V}$ のバイアス電圧条件下で表 1 に示す皮

Table 1 Coating conditions of films.

\begin{tabular}{c|c}
\hline Film & Substrate Temperature \\
\hline TiN & $450^{\circ} \mathrm{C}$ \\
\hline Ti-TiN & $450^{\circ} \mathrm{C}$ \\
\hline Ti-TiC-TiN & $450^{\circ} \mathrm{C}$ \\
\hline Ti-TiC-TiN & $300^{\circ} \mathrm{C}$ \\
\hline Non coating & - \\
\hline
\end{tabular}


膜の形成を行った。

なお，ガラス基板（コーニング7059）上にバイアス印 加電圧 $0 \mathrm{~V}$ の条件で $\mathrm{TiN} / 150^{\circ} \mathrm{C}$ (基板温度) 処理した試 料も比較材として用いた。

蒸発材料には純度 $99.9 \%$ 真空溶解チタンを，また窒 素, 炭素供給源には，それぞれ99.999\%，99.4\%の室素 ガス及びアセチレンガスを用いた。

\section{2 酎食性評価試驗}

イオンプレーティング処理した各試料の耐孔食性は, 動電位法 ${ }^{13}$ により $30^{\circ} \mathrm{C} の 3 \% \mathrm{NaCl}$ 水溶液中で測定した アノード分極曲線とそれから求めた孔食電位 $\left(V{ }^{\prime}{ }^{\prime}{ }^{\prime}\right)$ ), 自然電位 $\left(E_{\text {corr }}\right)$ の経時変化, 及び $40^{\circ} \mathrm{C} の 0.1 \% \mathrm{NaClO}$ 水溶液 (次亜塩素酸ソーダ, $\mathrm{HCl}$ でpH 3 及び 7 に調整) 水溶液中での重量減少量から評価した。なお， $V c^{\prime}{ }_{100}$ は アノード電流密度が $1 \mathrm{~A} / \mathrm{m}^{2}$ に達した時の電位とした。 また，試料を溶液に一週間浸せきし，その前後の重量変 化の值を重量減少量とし, 重量减少量加ら平均腐食速度 $\left(\mathrm{g} / \mathrm{m}^{2} \cdot \mathrm{h}\right)$ を算出した。

一方, 耐すきま腐食性を評価する場合， $E_{\mathrm{R}}$ 測定用の 試料は $\phi 18$ と $\phi 32 \mathrm{~mm}$ の試料を, 自然浸せき試験用の試 料は $\phi 32 \mathrm{~mm}$ の試料 2 枚をそれぞれ重ね合わせ, 中央穴 を通したポリカーボネート製ボルトナットで締め付ける ことによりすきまを構成した ${ }^{14)}$ 。すきま䋀食開始電位 $\left(V_{\text {crev100 }}^{\prime}\right)$ 及び $E_{\mathrm{R}}$ の測定は, 試料を $30^{\circ} \mathrm{C}$ の $3 \% \mathrm{NaCl}$ 水 溶液中に $5 \mathrm{~min}$ 間浸せき後, 前報 ${ }^{14)}$ で述べた電気化学的 測定法に準じて定電位操作することにより行った。なお,

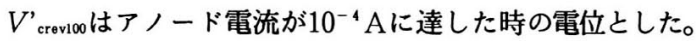
また，自然浸せき試験においては，試料を $40^{\circ} \mathrm{C} ， 3 \%$ $\mathrm{NaCl}$ 水溶液中に 1 ケ月間浸せきした後の重量減少量か ら耐すきま腐食性を評価した。

なお, 電解溶液は $V c^{\prime}{ }_{100}$ を測定する場合にはAr脱気, その他の場合にはいずれも大気開放下の条件とし，照合 電極には飽和カロメル電極（SCE）・を用いた。

また, 皮膜解析や腐食形態の観察には, 走查型電子顕 钽鏡 (SEM), 波長分散型X線マイクロアナライザー
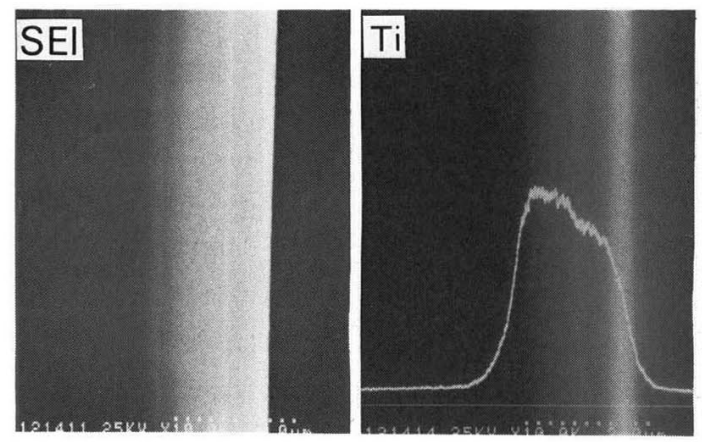

（EPMA）及びCu-K $\boldsymbol{\alpha}$ のターゲットを用いた薄膜X線 回折装置を用いた。

\section{3. 実験結果及び考察}

\section{1 生成皮膜の解析}

膜厚は，機械的に破壊した皮膜の破面のSEM観察及 び皮膜断面のEPMAによる線分析結果から判断して, Ti-TiN $/ 450^{\circ} \mathrm{C}, \mathrm{Ti}-\mathrm{TiC}-\mathrm{TiN} / 450^{\circ} \mathrm{C}$ が約 $1 \mu \mathrm{m}$, TiN $/ 450^{\circ} \mathrm{C}$, Ti-TiC-TiN $/ 300^{\circ} \mathrm{C}$ が $2 \sim 3 \mu \mathrm{m}$ であった。図 1 に一例としてTi-TiC-TiN $/ 300^{\circ} \mathrm{C}$ の断面の線分析結果 を示す。 $\mathrm{Ti}, \mathrm{C}, \mathrm{N}$ 分布から膜厚の確認ができると同 時に, TiCとTiNの存在も予測できる。なお, Ti-TiC$\mathrm{TiN} / 450^{\circ} \mathrm{C}$ においては膜厚が約 $2 \mu \mathrm{m}$ の試料も作製し, 孔食電位測定用とした。図 2 に示すように, 皮膜表面は 比較的平坦であり, 機械的に破壊した皮膜の破面は柱状 組織を呈し，皮膜表面に対してほぼ垂直に割れた。

図3に各皮膜のX線回折結果を示す。TiN皮膜は，い ずれあ（111）配向が強い。また, $\mathrm{TiN} / 450^{\circ} \mathrm{C}$ の表面を EPMAにより組成分析した結果, この皮膜はN/Ti原子 比こ0.75となり, 化学量論比 $1: 1$ に近い組成を持つ膜
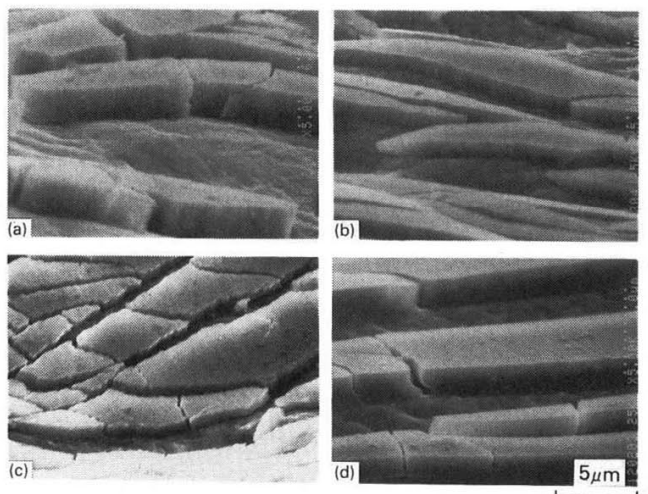

Fig. 2 SEM images of mechanically broken films.
(a) $\mathrm{TiN} / 450^{\circ} \mathrm{C}$
(b) $\mathrm{Ti}-\mathrm{TiN} / 450^{\circ} \mathrm{C}$

(c) $\mathrm{Ti}-\mathrm{TiC}-\mathrm{TiN} / 450^{\circ} \mathrm{C}$

(d) $\mathrm{Ti}-\mathrm{TiC}-\mathrm{TiN} / 300^{\circ} \mathrm{C}$
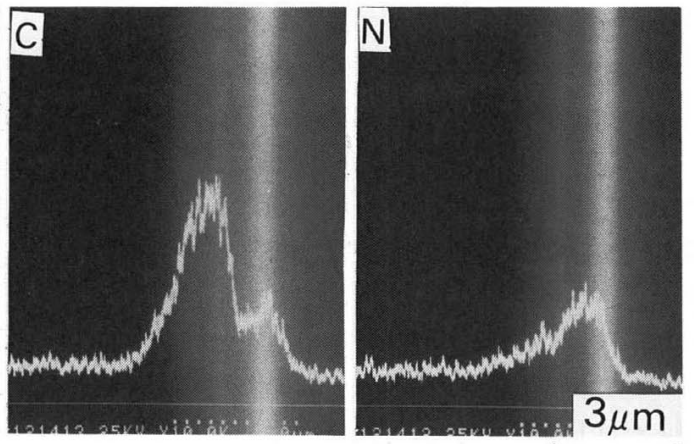

Fig. 1 SEM and line analysis of $\mathrm{Ti}, \mathrm{C}$, and $\mathrm{N}$ contents of cross section of $\mathrm{Ti}-\mathrm{TiC}-\mathrm{TiN} / 300^{\circ} \mathrm{C}$. 


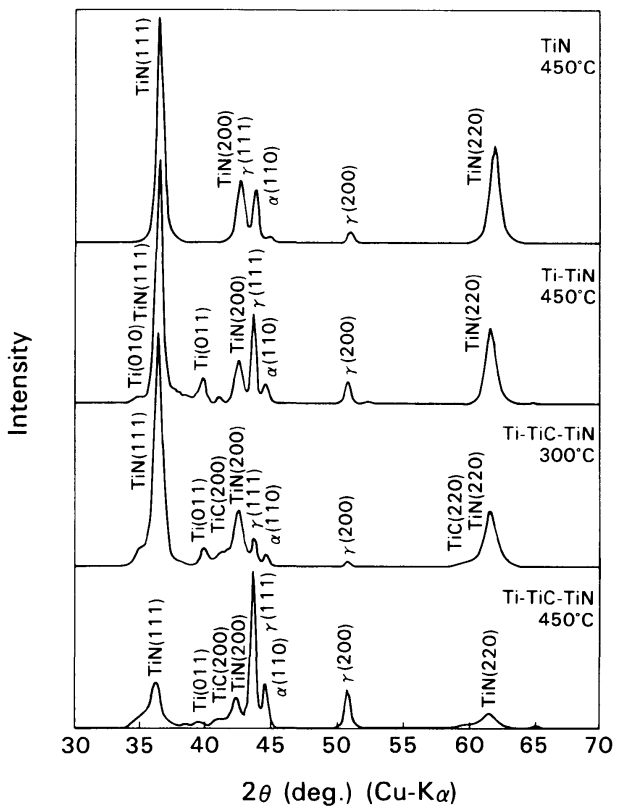

Fig. 3 X-ray diffraction patterns of films.

であることがわかった。EPMAで薄膜の組成分析を行 う場合，母材側の影響を防ぐために皮膜の厚さはX線発 生領域より厚くする必要がある。西田ら ${ }^{15)}$ は, EPMA の加速電圧を $10 \mathrm{kV}$ とした場合, TiNの膜厚が2.5 $\mu \mathrm{m}$ 前 後であれば皮膜厚さはX線発生領域を越えており, 分析 が可能であることを報告している。本実験用試料におい ても, 皮膜厚さは $2 \sim 3 \mu \mathrm{m}$ あることから $\mathrm{TiN}$ の組成分 析は可能と判断できる。なお, Ti-TiC-TiN $/ 450^{\circ} \mathrm{C} に お ~$ いてTiN(111)のピークが低く，母材のピーク (111) $\gamma$ が 高いのは, 皮膜が薄かったためと考えられる。さらに, 積層したもの（多層膜）からは, TiあるいはTiCの存在 あ認められるが，これらは前述したようにEPMAの結 果からも支持される。また，ガラス基板上においても (111)配向の強いTiN皮膜が形成された。

\section{2 耐孔食性}

図 4 に $30^{\circ} \mathrm{C}$ の $\% \mathrm{NaCl}$ 水溶液中での各試料のアノ一 ド分極曲線を，図 5 に $V c^{\prime}{ }_{100}$ を示す。図 4 で明らかなよ うに, 未処理材の場合, 活性態域においてアノード溶解 ピークが認められる。また，不動態域においても電位が 貴になると，孔食の発生と再不動態化の繰り返し ${ }^{16)} に よ$ る電流の変動が認められ, 不動態が不安定であることが わかる。さらに, $0.2 \mathrm{~V}$ 付近まで電位を掃引すると孔食 の発生, 成長に起因した電流の増大が認められる。

一方，TiN処理した試料はいずれあ活性態域でのアノー ド反応が抑制され，比較的貴な電位まで不動態が安定し ている。特にTiをアンダーコートした試料は，未処理 材に比べて孔食電位が貴となり耐孔食性が改善される。

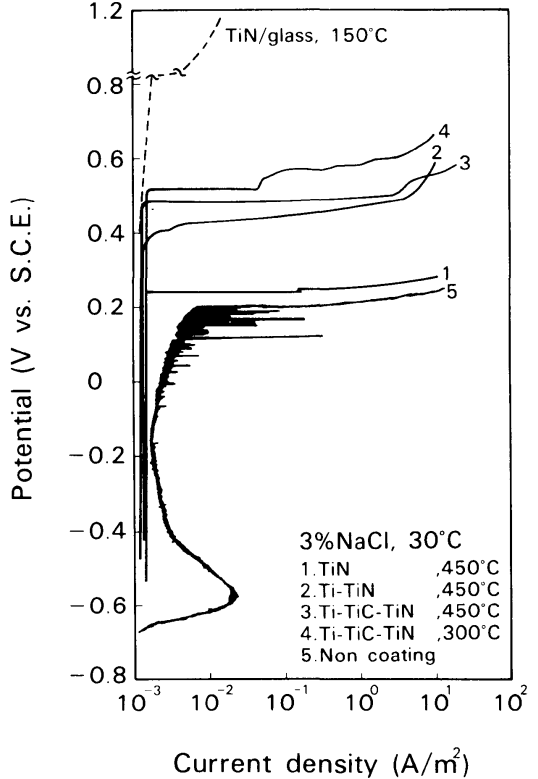

Fig. 4 Anodic polarization curves of the specimens in $3 \%$ $\mathrm{NaCl}$ solution at $30^{\circ} \mathrm{C}$.

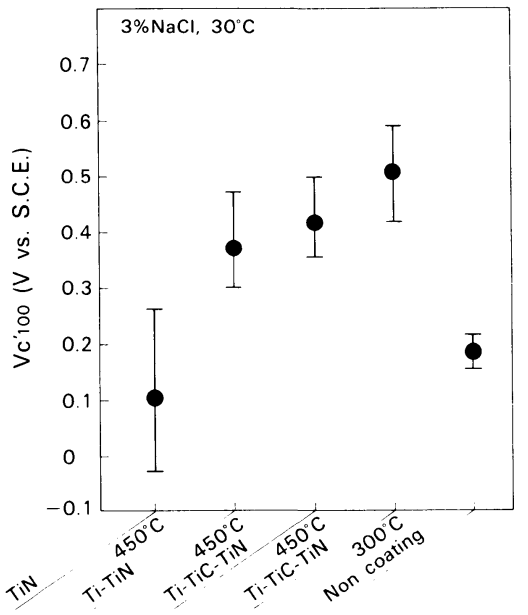

Fig. $5 V c^{\prime}{ }_{100}$ of the specimens in $3 \% \mathrm{NaCl}$ solution at $30^{\circ} \mathrm{C}$.

しかし，ほぼ酸素発生域までアノード電流の増大が認め られないTiN/ガラス試料と比べると孔食電位は著しく 卑である。これは, 皮膜が欠宿を含んでいるために十分 な環境遮断効果を示さず，孔食電位が母材の影響を受け ていることを示唆している。特に, TiNのみの試料は, 図 5 に示すようにバラッキによっては $V c^{\prime}{ }_{100}$ が未好理材 よりあ早となる場合がある。これは，皮膜形成時の加熱 によって母材が鋭敏化され，母材自体の耐孔食性が低下 していることに加え, TiNのみの場合, 皮膜の欠宿が Tiアンダーコートしたあのよりあ多いということに起 因しているあのと考えられる。 
Ti-TiC-TiN $/ 300^{\circ} \mathrm{C}$ は $V{ }^{\prime}{ }_{100}$ が最も貴で, Ti-TiC-TiN $/ 450^{\circ} \mathrm{C}$ よも而孔食性が優れている傾向にある。TiTiC-TiN $/ 450^{\circ} \mathrm{C}$ はTi-TiC-TiN $/ 300^{\circ} \mathrm{C}$ に比べて皮膜が薄 いために耐孔食性が低下したことも考えられるが，2 $\mu \mathrm{m}$ に皮膜を增した試料についてあ $V \mathrm{C}^{\prime}{ }_{100}$ を測定してみ たところ，その值はいずれあ同様の範囲に入り耐孔食性 の改善は認められなかった。従って, $450^{\circ} \mathrm{C}$ 処理材と 300 ${ }^{\circ} \mathrm{C}$ 処理材とで而孔食性が異なる主な原因は膜厚以外にあ るあのと考えられる。

イオンプレーティング処理時に基板表面に酸化膜が存 在すると皮膜の密着性が低下するため, 皮膜形成前にス パッタクリーニングなどが行われている。しかし，一般 にステンレス鋼は非常に不動態化しやすい金属であり,

酸素之の親和力が大きく, 通常イオンプレーティング処 理が行われる $10^{-2} \mathrm{~Pa}$ 前後の真空度では, 再酸化が起こ りうると考えられるが, この傾向は温度が高いほど顕著 であると推定される。また, 基板と皮膜の熱膨張率の差 （SUS 304，TiC，TiNの熱膨張係数はそれぞれ18.7, 7.7 及び $\left.9.3 \times 10^{-6} /{ }^{\circ} \mathrm{C}\right)$ から皮膜に生じる残留応力は, 高温から冷却したものほど大きくなり, 割れ，はく離な ど皮膜欠陥を誘発する原因となることが考えられる。門 $ら^{177}$ は, TiN/SUS 304の場合, 大きな圧縮残留応力の ため皮膜中に存在する久宿は化学的に不安定となり, 分 極試験中に容易にピンホールを形成することを報告して いる。こうしたことからSUS 304 鋼では, $450^{\circ} \mathrm{C}$ 処理材 は $300^{\circ} \mathrm{C}$ 処理材に比へ耐孔食性が低下することが考えら れる。

なお，多層構造であるほど素地に達する欠宿が減少し， また, 中間層としてTiCを積首化すると層間密着性が向 上し皮膜が強勒化して皮膜欠陥の抑制につながることが 経験的に知られている。こうしたことから, 耐食性の改

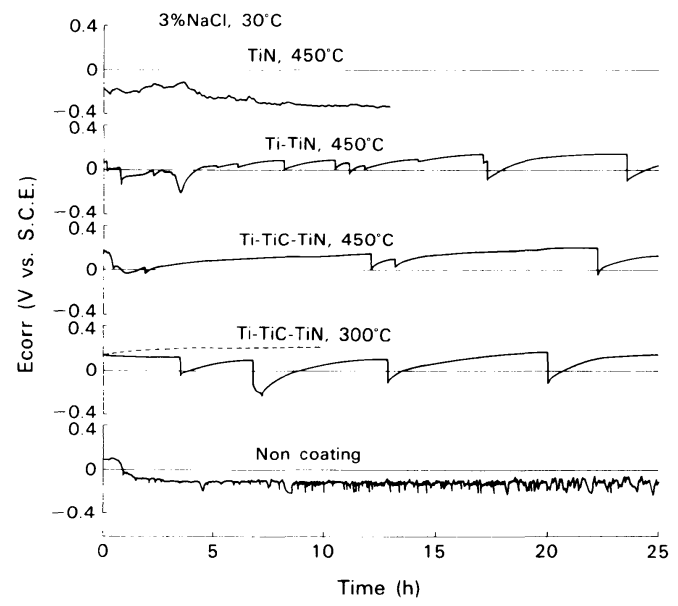

Fig. 6 Change in the corrosion potential of the specimens in $3 \% \mathrm{NaCl}$ solution at $30^{\circ} \mathrm{C}$.

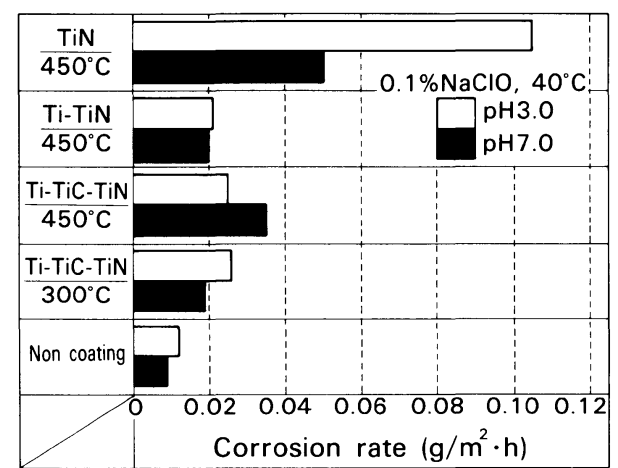

Fig. 7 Corrosion rate of the specimens in $0.1 \% \mathrm{NaClO}$ solution at $40^{\circ} \mathrm{C}$.

善に及ぼすTiC積層の効果が期待されたが，Ti-TiN/ $450^{\circ} \mathrm{C}$ と Ti-TiC-TiN $/ 450^{\circ} \mathrm{C}$ との比較で明らかなように $V \mathrm{C}^{\prime}{ }_{100}$ はTi-TiC-TiN $/ 450^{\circ} \mathrm{C}$ の方が若干貴となる傾向に はあるものの，両試料間に顕著な差は認められなかった。

図 6 に $30^{\circ} \mathrm{C}$ の $3 \% \mathrm{NaCl}$ 水溶液中での $E_{\text {corr }}$ の経時変化 を示す。 $E_{\text {corr }}$ はTiNのみの場合, 活性態域にとどまるの に対して, その他の処理材の場合には不動態域と活性態 域の間を周期的に变動する傾向を示し， $E_{\text {corr }}$ の経時変化 にあTiアンダーコートの有無による顕著な相違が認め られる。すなわちTiNのみの場合, 浸せき直後から活性 態腐食が連続して進行するが，Tiアンダーコートした 場合には，一旦腐食が起こってあある程度まで腐食が進 むと再不動態化してしまうことを示している。再不動態 化の理由は, アノードとして作用する皮膜欠陥部の面積 がカソード面積に比べて著しく小さく，欠宿部に集中す る電流密度が一時的に不動態化限界電流密度を越えてし まうことにある。なお, Ti-TiC-TiN $/ 300^{\circ} \mathrm{C}$ の部の試 料は破線で示すように $E_{\text {corr }}$ が全く活性態域に落ち込まず, 不動態域にとどまるものも認められ，この結果から300 ${ }^{\circ} \mathrm{C}$ 処理材は $450^{\circ} \mathrm{C}$ 処理材に比べて皮膜欠宿が少ないこと が示唆される。

図 7 は $40^{\circ} \mathrm{C}$ の $0.1 \% \mathrm{NaClO}$ 水溶液に各試料を自然浸せ きした場合の腐食速度を示す。いずれの処理材む未処理 材に比べて腐食速度が大きい。これは，重量減少量がは く離した皮膜の重量を含んでいることにも原因があるが, いずれの処理材においてあ，強腐食環境下では一旦孔食 が発生した後の腐食の進行は, TiN皮膜によって促進さ れることを示唆している。 $\mathrm{H}_{2} \mathrm{SO}_{4}$ 中の結果 ${ }^{18)}$ から推察す ると，TiN被覆することによってカソード反応が抑制さ れ，腐食抑制につながると考えられる。しかし，図７に 示したように自然浸せき条件下で腐食反応が促進させら れた理由は, カソードとして作用するTiNの電位が母材 よりあ著しく貴であったため, 反応のDriving force, 


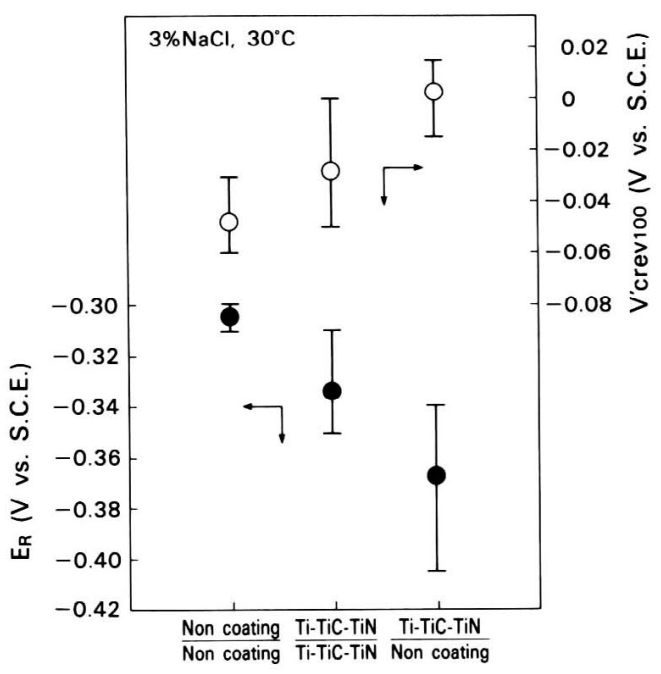

Fig. $8 V_{\text {crov100 }}^{\prime}$ and $E_{\mathrm{R}}$ of the specimens in $3 \% \mathrm{NaCl}$ solution at $30^{\circ} \mathrm{C}$.

すなわち電位差が大きくなったためであると考えられる。

\section{3 耐すきま腐食性}

図 8 に $30^{\circ} \mathrm{C}$ の $3 \% \mathrm{NaCl}$ 水溶液中で, Ti-TiC-TiN $/ 450$ ${ }^{\circ} \mathrm{C}$ どうし, Ti-TiC-TiN $/ 450^{\circ} \mathrm{C}$ と末処理材, 未処理材ど うしの組み合せで， $V^{\prime}{ }^{\prime}{ }_{\text {revv100及び }} E_{\mathrm{R}}$ を測定した結果を示 す。Ti-TiC-TiN $/ 450^{\circ} \mathrm{C}$ どうしの場合， $V^{\prime}{ }_{\text {erevvoo }}$ は貴とな るが $E_{\mathrm{R}}$ は卑となる。すなわち，TiN処理材はすきま腐 食は起こりにくいが，一旦起こると再不動態化しにくい ことを示している。Ti-TiC-TiN $/ 450^{\circ} \mathrm{C}$ と処理材との 組み合せではその傾向が一層明瞭となる。TiN被覆によっ てE $E_{\mathrm{R}}$ が卑となる理由の一つとして，すきまの幾何学的 条件の変化 ${ }^{19}$ が挙げられる。すきま腐食は，すきま内の 腐食に関与する物質移動が妨げられる結果起こる現象 ${ }^{20)}$ である。皮膜欠陥部で庽食が起こり，母材中へ深くある いは皮膜と母材との界面に沿って複雑な形状で腐食が進 行すると，すきま内は物質移動が妨げられ，金属塩化物 の濃縮, $\mathrm{pH}$ の低下が起こり, 不動態皮膜の溶解が一層 容易になるため再不動態化が抑制され， $E_{\mathrm{R}}$ が杽になっ たあのと考えられる。また, Ti-TiC-TiN $/ 450^{\circ} \mathrm{C}$ と末処 理材との組み合せにおいては，他の組み合せに比べてす

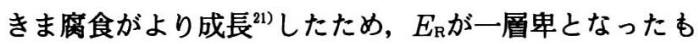
のと考えられる。

図 9 は $40^{\circ} \mathrm{C}$ の $3 \% \mathrm{NaCl}$ 水溶液にすきまを形成した試 料を自然浸せきした場合の腐食速度を示す。TiNのみの 組み合せの場合, 腐食速度は著しく大きい。これは, Tiアンターコートなしの場合, TiN皮膜の密着性が弱 いために皮膜はく離が起こりやすく，母材と皮膜界面で の腐食が著しく進行しやすいことに起因した結果と考え られる。一方, Tiアンダーコートした試料は皮膜のは く離がほとんど認められず，欠陥部が拡がらないために

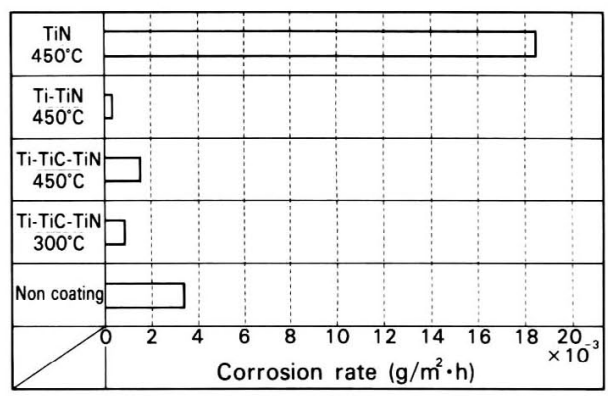

Fig. 9 Corrosion rate of the specimens in $3 \% \mathrm{NaCl}$ solution at $40^{\circ} \mathrm{C}$.
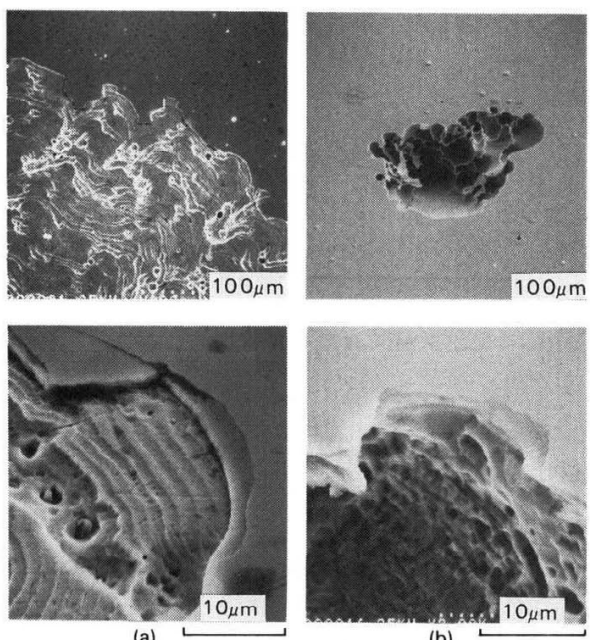

(b)

Fig. 10 Corrosion morphology after the anodic polarization in $3 \% \mathrm{NaCl}$ solution at $30^{\circ} \mathrm{C}$.
(a) $\mathrm{TiN} / 450^{\circ} \mathrm{C}$
(b) $\mathrm{Ti}-\mathrm{TiN} / 450^{\circ} \mathrm{C}$

(一種のアノード律速), 未処理材よりも腐食速度が小さ くなったものと考えられる。

通常, $E_{\mathrm{R}}$ はすきま腐食発生の下限界電位 $\left(V_{\text {crev }}\right)$ に 一致する ${ }^{199}$ 。これから考えると，処理材は图 8 に示した ように $E_{\mathrm{R}}$ が卑となることから，それだけ不動態保証電 位域が狭くなり，耐すきま腐食性が低下することになる。 しかし, Tiアンダーコートした場合にはTiN皮膜の密 着性が向上するために TiN被覆によるカソード反応抑制 効果が現れ, 自然浸せき条件下においては未処理材に比 べて腐食速度が小さくなるすのと推察される。

\section{4 腐食形態}

図10に孔食電位測定後の腐食形態のSEM写真を示す。 TiNのみの試料は広く浅く腐食しており, 母材に特有の 波状紋が認められる。拡大すると皮膜は母材との界面で はく離しており，母材の界面での浸食に対応して次々と 剥がれ落ちていったものと推定される。一方, Tiアン 


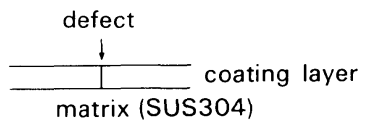

without Ti coating $\square \quad \backsim \quad$ with Ti coating
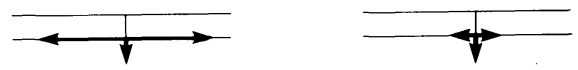

3
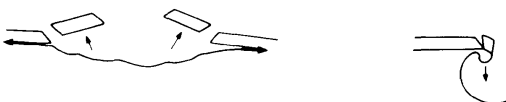

Fig. 11 Schematic illustration of corrosion behavior.

ダーコートした試料は，腐食孔があまり拡がらず母材部 が深く浸食されている。また，皮膜と母材とのはく離は ほとんど認められない。

なお，皮膜は，機械的に破壊した場合には図 2 に示し たように皮膜表面に対してほぼ垂直に割れるのに対し， 腐食によって破壊された場合には暨開状に斜めに割れて いる部分が多かった。

以上のような腐食形態から推定される腐食挙動を模式 的に図11に示す。Tiアンダーコートの有無に係わらず, まず皮膜の欠宿部から腐食が始まる。Tiアンダーコー トなしの場合, 皮膜と母材との密着性が弱いためにそれ らの界面に腐食媒体の浸透が起こりやすく，界面がすき ま腐食的に優先的に腐食し，皮膜はく離が急速に進む。 次いで皮膜が母材から浮いた状態となり，ある程度大き くなると支えきれなくなり欠け落ちる。これが絽り返さ れるために母材部の浸食は深くならず, 特有の波状紋が 形成される。一方, Tiアンダーコートした場合, 皮膜 と母材との密着性が優れているために界面での腐食が進 行しにくく，母材部の腐食が深さ方向に優先的に進む。 そして皮膜下の母材が溶出した後に皮膜が欠け落ちる。

なお，腐食に伴う割れは機械的な割れと形態を異にす

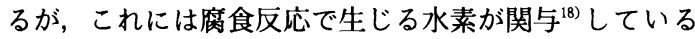
あのと考える。

\section{4. 結言}

HCD式の工業炬にて種々の条件でSUS 304 鋼上に TiN皮膜を形成し，主に電気化学的方法によって塩化物 水溶液中での耐孔食性並びに耐すきま腐食性の評価を行っ た結果，次のことが明らかとなった。

(1) TiC積層や皮膜形成温度が耐孔食性，耐すきま腐食性 に与える影響は少なく，Tiアンダーコートの有無によ
る差が顕著である。Tiアンダーコートすることにより, 腐食形態にも差が認められる。

(2)Tiアンダーコートなしの場合, TiN処理することに より耐孔食性及び而すきま腐食性が未処理材よりあ低下 する。これは皮膜が多くの欠宿を含み，また，皮膜と母 材之の密着性が悪いために, 皮膜と母材の界面で起こる 腐食が優先し，それに起因して皮膜はく離が促進される ことによる。

(3)Tiアンダーコートした場合, TiN処理材は孔食電位 が貴となり耐孔食性が向上する。また，すきま腐食開始 電位が貴となり，すきま腐食発生に対する抵抗が大きく なる。これは皮膜の欠陥が少なく，さらに，皮膜の密着 性が向上したことによるあのと推定される。しかし，一 旦腐食が始まった場合には, 再不動態化電位が卑となり, 再不動態化が抑制される。

終わりに，本研究にご協力をいただきました芝浦工業 大学学生, 玉井章喜君 (現在, 三桜工業株式会社), 並 びに有益なご助言を賜りました東京都立工業技術センター 仁平宣弘氏，棚木敏幸氏に感謝の意を表します。

(1989-12-25 受理)

\section{文献}

1) R. Buhl, H. K. Pulker, E. Moll ; Thin Solid Films, 80, 265 (1981)

2 ) Y. Murayama ; J. Vac. Sci. Technol., 12, 818 (1975)

3 ) H. Yoshihara and H. Mori ; J. Vac. Sci. Technol., 16, 1007 (1979)

4 ）松村義人，黄 燕清；金属表面技術，35，39（1984）

5 ) R. E. Jacobson; Thin Solid Films，63，333 (1979)

6 ）渋木邦夫，塚本哲治，高津宗吉；金属表面技術，35，77 (1984)

7 ）高橋夏木；金属表面技術，34，16（1984）

8 ）岸 松雄, 渡辺 昭, 下山良造 ; 金属表面技術, 35，50 (1984)

9 ）仁平宣弘；プラズマを利用した表面処理技術，東京都立工 業技術センター編, p. 1 (1988)

10）西田典秀, 川崎仁士, 本田和男, 細川智生; 金属表面技術, 37, 346 (1986)

11）市村博司 ; セラミックス，24，433（1989）

12）滝沢貴久男；表面技術，40，988（1989）

13）滝沢貴久男, 志水康彦, 樋口義弘, 田村今男; 鉄之鋼, 70, 741 (1984)

14）滝沢貴久男，志水康彦，樋口義弘，田村今男；金属表面技 術, 36, 265 (1985)

15）西田典秀, 横山文男 ; 金属表面技術，36，330（1985）

16）塩原國雄, 森岡 進 ; 日本金属学会誌，36，471（1972）

17）門 哲男, 真壁遼治, 望月昭一, 中島貞夫, 荒木道郎; 防 食技術，36，551（1987）

18）黒河圭子, 小平隆志, 福島 誠, 澺沢貴久男, 今井八郎 ; 表面技術協会第80回講演大会講演要旨集, p.126（1989）

19）辻川茂男，久松敬弘；防食技術，29，37（1980）

20）鈴木紹夫；防食技術，28，38（1979）

21）黑河圭子, 小平隆志, 中山佳則, 滝沢貴久男, 今井八郎 ; 表面技術，40，792（1989） 